Available online at: http://journal.uny.ac.id/index.php/litp
LingTera, 5 (1), 2018, 32-40

\title{
An analysis and evaluation of two English textbooks for second graders of junior high school
}

\author{
Anita Nur Masyi'ah *, Dyah Setyowati Ciptaningrum \\ Department of Department of English Language Education, Program Pascasarjana, Universitas Negeri \\ Yogyakarta. Jalan Colombo No. 1, Karangmalang, Yogyakarta, 55281, Indonesia \\ * Corresponding Author. Email: anitanurmasy@gmail.com \\ Received: 19 July 2017; Revision: 10 September 2018; Accepted: 12 September 2018
}

\begin{abstract}
This study is important because teachers need to know the strengths and weaknesses so that teachers can decide what actions should be taken related to t. It becomes more significant because teachers, especially in Indonesia, rarely evaluate textbooks before using them. This study aimed at: (1) discovering the textbooks quality based on the criteria from some ELT experts and Pusat Perbukuan, and (2) identifying the strengths and weaknesses of students' textbooks entitled When English Rings a Bell and Bright for Grade VIII. The data were collected using checklists distributed to two English teachers. The scores then were accumulated to find the average before the final score was rated using the category from Pusat Perbukuan and ELT experts. The results showed that When English Rings a Bell has fulfilled the criteria of a fair textbook (78.6\%). The book has some strengths and weaknesses, such as providing materials covering the local culture, lacking some retention, and the like. Meanwhile, Bright is a good textbook (87.2\%) with some strengths and weaknesses, such as providing materials containing target culture, lacking materials containing local culture. The results show that When English Rings a Bell is a fair textbook and Bright is a good textbook with their strengths and weaknesses.
\end{abstract}

Keywords: textbooks analisis and evaluation, textbooks, second graders of JHS

How to Cite: Masyi'ah, A., \& Ciptaningrum, D. (2018). An analysis and evaluation of two English textbooks for second graders of junior high school. LingTera, 5(1), 32-40. doi:http://dx.doi.org/10.21831/lt.v5i1.14931

http://dx.doi.org/10.21831/lt.v5i1.14931

\section{INTRODUCTION}

The importance of English in this globalization era has made people try to improve their English in order to communicate well with people all over the world. Therefore, English has been one of the compulsory subjects for junior and senior high school students in Indonesia (Nuh, 2013). Recently, the government has launched Curriculum 2013 which aims at preparing religious, productive, creative and innovative generations of this country. It is characterized by the implementation of Scientific Approach and is organized into Core and Basic Competences (Ministry of Education and Culture, 2013).

As the new curriculum is implemented, there are changes in the educational system, including the teaching materials. One of the most famous teaching materials are textbooks. Textbooks need to be designed based on the new curriculum. Brown (2001, p.136) claims that textbooks are the most common materials for teaching and learning process. The change of the curriculum is well-reflected through the textbooks because once a new curriculum is introduced, a number of textbooks are designed and published.

Textbook evaluation is important to be conducted because teachers show quite big dependency toward textbooks to teach in the classroom. A study conducted by Ena (2013, p. 3) shows that in Indonesia, many Indonesia EFL teachers use textbooks as the only instructional materials to teach students. It also means that they depend so much on the commercial textbooks which are available in the market.

The results of textbook evaluation are beneficial for teachers to be able to help them decide actions which should be taken related to the strengths and weaknesses of the textbooks. The textbook chosen in this study are When English Rings a Bell for Grade VIII Students and Bright: An English Course for Junior High 
School Students Grade VIII. When English Rings a Bell was published by the Ministry of Education and Culture while Bright was developed by Nur Zaida and published by Erlangga. They were chosen because they are designed based on Curriculum 2013 and there were no evaluation and analysis of those two textbooks provided for public. Also, based on the interview in some bookstores, they are two of the most best-selling ones in Yogyakarta and Bantul. Because of the unavailability of the analysis of both textbooks, the way to find out the quality and also the strengths and weaknesses is by evaluating them.

There are several definitions of textbooks stated by some experts. According to Brown (2001, p. 267), textbooks are the most common materials for teaching and learning process. Meanwhile, Cunningsworth (1984, p.1) defines textbooks as books which are written and developed by experts. The materials usually have been tested in a pilot study in real teaching situation before they are published to public.

Textbooks have several important functions. Some functions of them are noted by Cunningsworth in Richards (2001, pp. 251-252). They are: (1) as resources for presentation materials, it can be spoken or written materials; (2) as sources of activities for the students to practice their communicative interactions in order to communicate well in the real life; (3) as references to learn grammar, vocabulary, pronunciation and other aspects of English; (4) as sources of ideas for designing activities and tasks to teach students; (5) as guidance or syllabus that can reflect the learning objectives which have been determined from the beginning of the stage, and; (6) as supports for teachers in teaching.

Generally, textbook evaluation is a process which is conducted to know the quality of textbooks. Cunningsworth $(1995$, p. 9$)$ postulates that the process of judging the book is based on the views and priorities of the parties conducting it. Wahab (2013, p.56) points out several reasons why people evaluate or analyse textbooks. The first major reason is to adopt new course books to be used to teach or learn. The next reason is to find out specific strengths and weaknesses in the existing materials so that the further actions can be taken. The last possible reason is that it can actually be beneficial for the teachers' development in teaching.

Textbooks should be designed based on a curriculum. Curriculum 2013 is the newest and current curriculum implemented in Indonesia starting from the academic year of 2013/2014.
This curriculum emphasizes the integration of the development of character, knowledge and also skills. It is clearly reflected in the organization of the competences (Ministry of Education and Culture, 2013). The competences in this curriculum are organized into three types, namely religiousness, social characters, knowledge and skills. Those competences then later on become the basis of the development of basic competences which eventually are broken down into further details in order for the competences can be more feasible and achievable.

One important thing about this curriculum is that it is characterized by the application of scientific approach in the instructional process in almost all subject matters, including English. Scientific approach has one particular goal that is to engage the students in five steps of inquiry, namely observing, questioning, collecting information, associating, and communicating (Ministry of Education and Culture, 2013).

\section{Textbook Evaluation Criteria}

\section{Criteria by Pusat Perbukuan BSNP}

In evaluating the textbooks, some textbook evaluation criteria can be used as guidance. One of them is the one proposed by Pusat Perbukuan $B S N P$. It is the institution for regulating textbooks which are used in Indonesian educational system. The instruments offer three major areas to be investigated namely content, language and presentation aspects. The content aspect is intended to analyse the appropriateness of the content in the textbooks. The language is the second aspect which needs to be evaluated. The last aspect is the presentation which is related to the technique of presentation, the technique of teaching and learning and the presentation coverage. (Pusat Perbukuan BSNP \& BSNP (2011, pp.1-22 \& pp. 1-10)).

\section{Criteria by Tomlinson}

Tomlinson (1998, pp. 7-21) also proposes textbook evaluation criteria. Good materials are really important and needed in order to make sure that the teaching and learning process can run effectively. Tomlinson (1998) proposes some characteristics of good materials.

The first characteristic is that the materials need to achieve impact. The next one is that it will be very good if the materials can help the students to feel at ease. Materials are good if they can help the learners to develop confidence. Dulay, Burt, and Krashen (Tomlinson, 1998) described that 
relaxed and self-confident students can actually learn the target language better.

The next characteristic is that what is being taught should be received by learners as relevant and useful. When learners know that the materials taught are what they need to know and will be useful for their daily life, they will do their best to learn the target language.There are also still some characteristics stated by Tomlinson.

\section{Criteria by Cunningsworth}

Another criterion is proposed by Cunningsworth (1995). There are several criteria serving as a guideline for developing checklist for the evaluation, namely; (1) corresponding to the learners' needs; (2) reflecting the present and future of language; (3) facilitating learning in various ways; and (4) having clear role as a support for learning.

Cunningsworth's framework for textbook evaluation has a comprehensive explanation on the internal approach to textbook evaluation. It also contains a criterion to evaluate the effectiveness of textbooks if they are seen from the perspective of the reality that students may face in their real life by presenting language beyond the classroom. However, this framework does not contain any criteria for evaluating the presentation, lay out, visual appearance and the like.

\section{Criteria by Byrd}

The next criterion is from Byrd (CelceMurcia (2001, pp. 415-420)) notes four main aspects to guide the textbooks evaluation process. The four aspects are content/explanations, examples, tasks/exercise, and presentation/format.

In short, Byrd's model of textbook evaluation has covered four main areas which are content/explanations, examples, tasks/exercises, and presentation/format. It also has a detailed explanation on each aspect which is evaluated. However, Byrd does not provide any measurable checklist to be used to judge the evaluated textbooks. The judgment technique of Byrd's framework is also not given.

Criteria by Littlejohn

Littlejohn (Tomlinson (2011, p. 179)) offers two major criteria for examining the worthiness of a textbook. They are publication and the design aspect. Publication aspect deals with the tangible aspect and also the textbook appearance as learning materials.

Design is the second criterion. It includes some aspects related to the aims of materials, the selection and sequence of tasks and also the activities, the content focus, and the nature of the teaching and learning process.

In conclusion, Littlejohn's framework to textbook evaluation has covered two main aspects, namely internal and external factors. The external factor offers a comprehensive explanation on the appearance, visual and lay out of the textbook. Meanwhile, the internal factor of Littlejohn's criteria focuses only on the underlying principles serving as a basis for developing textbooks. It does not really explore the texts and exercises in the textbooks.

\section{Criteria by Mukundan}

The next textbook evaluation criteria is proposed by Mukundan, Nimehchisalem and Hajimohammadi (2011, pp. 100-105). It consists of two major parts of textbook including general attributes and teaching-learning content.

\section{Criteria by Ur}

The last criteria is from Ur (1996, pp. 185188) who notes some criteria for evaluating textbooks. They consist of curriculum, graphic, tasks and topics, content, language and skills. However, it is stated that the criteria are flexible in nature. It means that the criteria can be added with the evaluator's criteria depending on the needs.

\section{Three Domains of Learning}

Beside the criteria from ELT experts, the three domains of learning should also be evaluated in order to ensure that the textbooks have covered the three domains. The purpose of curriculum is decided by its conductors based on the book entitled Taxonomy of Educational Objectives written by Benjamin Bloom which was published in 1956 (Nasution, 2008). The purpose of the study is divided into three main domains, namely cognitive, affective and psychomotor. Cognitive is the knowledge domain which is related to the students' thinking. Affective refers to the domain which is related to emotions and values. Meanwhile, psychomotor is related to the motoric creativity.

\section{Relevant Studies}

Similar type of research has been conducted to find out textbook quality. Fatima, Shah, and Sultan. (2015, p. 79) analysed and evaluated English textbooks entitled "Step Ahead 2 " and "Step Ahead 3" for $7^{\text {th }}$ and $8^{\text {th }}$ class respectively. They identified how well a pre-use 
textbook matched the needs of a learning program and how much appropriate the activities were. The textbooks were analysed impressionistically and with in-depth terminology. The results suggested some problematic areas that they need improvement related to the four skills and culture representation. There was an exposure of only foreign culture and basic skills were not emphasized equally. The findings accentuated the need to revisit the materials by the writers that could contribute to the improvements of the textbooks at these levels.

Another study was done by Lathif (2015) who did an evaluation of English textbooks for the eighth graders of junior high school. The first objective was to examine the appropriateness of the textbooks which were used by English teachers based on the criteria proposed by Pusat Perbukuan BSNP. The second objective was to find out whether the textbooks have fulfilled the criteria of good textbooks. The last objective of the research was to give some recommendations for teachers for the further actions they should decide related to the use of the textbooks to teach students. The books are Let's Talk: English for Students of Grade VIII and English on Sky 2 for Junior High School Students Grade VIII. The results showed that Let's talk: English for Students of Grade VIII have already fulfilled the criteria of good materials with the average fulfillment $80 \%$. Meanwhile, for the textbook entitled English on Sky 2 for Junior High School Students Grade VIII is a fair textbook as it achieved the average fulfillment score of $86 \%$.

Having been aware that the quality of the textbooks used is very important to be understood by the users, this study was conducted to find out the quality of two English textbooks mentioned previously. The results can help the users of the books whether the textbooks are appropriate to be used. The strengths and weaknesses which are provided can help the teachers to decide what actions should be taken to make the textbooks more suitable for the learners.

\section{METHOD}

The study implemented content analysis or document analysis technique and is classified as descriptive qualitative research. Ary, Jacobs, Sorensen, \& Razavieh (2010, p. 29) state that it focuses on evaluating and analysing the documents which were two students' textbooks in a systematic and replicable manner. It aimed at understanding and gaining the worthiness of English textbooks as shown by their strengths and also the weaknesses. The ones who evaluated the textbooks were the researcher and two English teachers.

The research objects were two English textbooks which are widely used in Yogyakarta and Bantul entitled When English Rings a Bell and Bright: an English course for Junior High School Students. When English Rings a Bell. The study implemented some steps proposed by Ary, et. al. (2010, p. 58). They were: (1) specifying the problem to investigate; (2) formulating the coding categories which were the criteria from ELT experts and Pusat Perbukuan; (3) deciding the objects; (4) analyzing the textbooks, and (5) writing down the report. The data were collected from two English textbooks for second graders of junior high school. The books were entitled Bright: an English course for Junior High School Students and When English Rings a Bell. They were designed based on the current curriculum which is Curriculum 2013.

The data were taken using the rubrics or checklists adapted and modified from the textbooks evaluation criteria from some ELT experts and Pusat Perbukuan BSNP. As this study was intended to evaluate textbooks, the checklists were used to gather the data (Ary, et. al., 2010). The checklists then were distributed to be evaluated by the researcher and two English teachers. The modification of Likert scales was used to rate the data. The scale from 1-4 were used whose descriptions are; 1 for disagree; 2 for disagree somewhat; 3 for agree, and; 4 for strongly agree.

The checklists were developed from seven major sources including from Pusat Perbukuan $B S N P$ (2011) and some ELT experts. The checklists consisted of four major aspects namely content, language, presentation and the affective, cognitive and psychomotor domains.

There were two methods applied to ensure the credibility and dependability of this study. They are consensus and triangulation (Ary, et.al, 2010). The descriptions are presented as follows.

\section{Consensus}

Qualitative study should employ consensus to ensure its credibility (Ary, et.al, 2010). In this study, it was done through peer debriefing technique applied by collaborative working between the researcher and her thesis supervisor. The researcher played the roles of planning, collecting, analyzing and reporting the research findings. She planned and decided the steps which would be followed in conducting the 
research, collected the data by evaluating the textbooks using the modified checklist together with the two English teachers, analyzed the data and reported the findings in a way that can be understood by the readers. The supervisor acted as the reviewer of this research. She checked the data gained from this study and recommended the parts which need improvements.

\section{Triangulation}

Ary, et. al, (2010) postulate that triangulation can be implemented by the use of multiple observers. In applying this theory, some strategies were implemented such as asking English teachers to act as investigators triangulation. The multiple researchers were the researcher and two English teachers of junior high school to examine the data. The data collected from them then were calculated so that the average could be found. By doing so, the maximum results could be achieved as the data were analyzed by more than one researcher. The English teachers together with the researcher evaluated the textbooks using the modified checklist. They were required to check whether the books have matched the statements in the items of the checklist. Teachers were chosen as this study was intended to be able to help them to decide what actions should be taken regarding the strengths and weaknesses of the textbooks. Moreover, the checklist was expected to be applicable to teachers so that they can adapt it to evaluate other textbooks they will use to teach

The calculation of the data analysis was given to each textbook. The data analysis was done using basic descriptive statistics by adding the total points in each item which have been converted to percentages. Then, they were calculated to find the average score of each sub aspect. From the average of the sub aspect, the average of every aspect was also calculated. The scores for the scales in the instruments are presented as follows.

\section{FINDINGS AND DISCUSSIONS}

The findings were derived from the results of checklists distribution to the English teachers and the researcher. They were then calculated to find the average. Textbook 1 refers to When English Rings a Bell and Textbook 2 refers to Bright. The results are presented as follows.

Based on the data presented on Table 1, Textbook 1 is categorized as "fair" by achieving the average fulfillment score of $78.6 \%$. Three criteria are classified as "good", namely the relevance of materials to the curriculum (81.6\%), presentation technique (87.5\%) and the affective, cognitive and psychomotor domains (83.2\%). Other aspects which are materials accuracy (77.6\%), supporting learning materials (75.4\%), language appropriateness $(72.1 \%)$, the teaching and learning technique (78.5\%) and presentation coverage $(73.3 \%)$ are categorized as "fair".

Table 1. Evaluation Summary

\begin{tabular}{|c|c|c|c|c|}
\hline \multirow{2}{*}{ Aspects } & \multirow{2}{*}{ No } & \multirow{2}{*}{ Sub-aspects } & \multicolumn{2}{|c|}{ Fulfillment } \\
\hline & & & T 1 & T 2 \\
\hline \multirow{3}{*}{ Content } & 1 & $\begin{array}{l}\text { Relevance of } \\
\text { Materials to the } \\
\text { Curriculum }\end{array}$ & 81.6 & 95 \\
\hline & 2 & $\begin{array}{l}\text { Materials } \\
\text { Accuracy } \\
\text { Supporting }\end{array}$ & 77.6 & 89.4 \\
\hline & 3 & $\begin{array}{l}\text { Learning } \\
\text { Materials }\end{array}$ & 75.4 & 81.1 \\
\hline \multirow[t]{2}{*}{ Language } & 4 & $\begin{array}{l}\text { Language } \\
\text { Appropriateness }\end{array}$ & 72.1 & 86.1 \\
\hline & 5 & $\begin{array}{l}\text { Presentation } \\
\text { Technique } \\
\text { Teaching and }\end{array}$ & 87.5 & 91.5 \\
\hline Presentation & 6 & $\begin{array}{l}\text { Learning } \\
\text { Technique }\end{array}$ & 78.5 & 86.8 \\
\hline & 7 & $\begin{array}{l}\text { Presentation } \\
\text { Coverage }\end{array}$ & 73.3 & 76.7 \\
\hline $\begin{array}{l}\text { Learning } \\
\text { Domains }\end{array}$ & 8 & $\begin{array}{l}\text { Affective, } \\
\text { Cognitive \& } \\
\text { Psychomotor } \\
\text { Domains }\end{array}$ & 83.2 & 91.2 \\
\hline \multicolumn{3}{|c|}{$\begin{array}{l}\text { Average }(\%) \\
\text { Criteria }\end{array}$} & $\begin{array}{l}78.6 \\
\text { Fair } \\
\end{array}$ & $\begin{array}{c}87.2 \\
\text { Good }\end{array}$ \\
\hline
\end{tabular}

On the other hand, the second textbook is categorized as "good" in terms of the overall average fulfillment score. It can be seen through the average fulfillment score which achieved $87.2 \%$. Out of eight proposed criteria, all of them but one were classified "good", namely the relevance of materials to the curriculum (95\%), materials accuracy $(89.4 \%)$, supporting learning materials $(81.1 \%)$, language appropriateness $(86.1 \%)$, presentation technique $(91.5 \%)$, the teaching and learning technique $(86.8 \%)$ and the affective, cognitive and psychomotor domains $(91.2 \%)$. The other criteria is categorized as "fair", namely the presentation coverage (76.7\%).

Related to the relevance of materials to the curriculum, Textbook 1 fulfils three of five proposed criteria. They are transactional texts, functional texts, and production aspects. The average fulfillment score of this aspect is $81.6 \%$ which means that Textbook 1 is "good" in terms of its relevance to the curriculum. Textbook 2 is 
also categorized as "good" by achieving average fulfillment score of $95 \%$. All of the criteria has fulfilled the requirement to be classified as good. This also means that this textbook is categorized "good" in the aspect of relevance to the curriculum.

With regard to the accuracy of the materials, Textbook 1 is categorized as "fair" since the average fulfillment score was $77.6 \%$. Only two of them fulfil the category of "good", which are about the generic structure of narrative and recount texts. On the other hand, Textbook 2 was classified as "good" by achieving the average fulfillment score of $89.4 \%$ which means that this book is good at its materials accuracy.

In terms of the supporting learning materials, Textbook 1 is categorized as "fair" with the average score of $75.4 \%$, whereas the other one achieves $81.1 \%$ which is classified as "good". Only six out of 14 sub-aspects in Textbook 1 fulfil the criteria of "good" textbook, namely the relevant sources for the supporting materials, personal skills, appreciation of cultural diversity and plural society, awareness of local and regional potential aspects, appreciation on democratic values, internalization on insight of national belonging and local culture. This means that Textbook 1 is categorized as "fair" in term of its supporting learning materials. Textbook 2, on the other hand achieves the average fulfillment score of $81.1 \%$ and is classified as "good". 10 sub-aspects have fulfilled the criteria. Those includes the up-to-date sources of supporting materials, personal skills, social skills, academic skills, vocational skills, cultural diversity and plural society appreciation, democratic values relevant to socio-cultural contexts, characters building and the promotion of English speaking countries culture. Therefore, Textbook 2 can be said as having good supporting learning materials.

In reference to the appropriateness of language, Textbook 1 achieves the average fulfillment score of $72.1 \%$ and is classified as "fair". The aspects which fulfil "good" criteria are the language of instruction which is suitable to students' socio-emotion condition, the readability of the messages, the grammatical accuracy, the unity and coherence in each unit, the sequence of the materials and good presentation and practice of pronunciation. This means that this textbook is categorized as "fair" in this category. The other textbook which is Textbook 2 was classified as "good" for achieving $86.1 \%$ of average fulfillment score.
Out of fifteen criteria, there are only three aspects which do not fulfilled the criteria of "good" in this aspect. They are the unity and coherence of all units/chapters, the presentation and practice of listening skill and the presentation and practice of vocabulary. Considering the results, the textbook is categorized as "good" in this category.

In accordance to the presentation in terms of their presentation techniques, both textbooks have met all the proposed criteria as "good" textbooks. They are (1) organization of presentation materials in the form of texts, communicative acts, illustrations, and symbols which consist of at least introduction, content, and conclusion and (2) balanced materials in the form of texts, communicative acts, illustrations and symbols.

Based on the criterion of teaching and learning technique, Textbook 1 is classified as "fair" by achieving the average fulfillment score of $78.5 \%$, whereas the second textbook has met all the proposed criteria to be categorized as "good" in this aspect with the average fulfillment score of $86.8 \%$.

In terms of their presentation coverage, both textbooks are categorized as "fair" with average fulfillment score $73.3 \%$ and $76.7 \%$. It is because both of them do not have glossary and index. Other aspects namely preface, table of content, introduction, learning load, reference, summary, reflection, and bibliography were present in the textbooks.

With regards to the affective, cognitive and psychomotor domains, both of the textbooks have fulfilled the criteria of "good" by achieving the average fulfillment score of $83.2 \%$ and $91.2 \%$. It shows that the books have covered the affective, cognitive and psychomotor domains of the students in learning English.

\section{The Summary of Strengths and Weaknesses of Each Textbook}

\section{Textbook 1}

Textbook 1 has been successful in providing many texts as models for students even though they are not really varied. It also provides sufficient materials which promote the local culture to make students aware of their identity and to introduce the local and national potentials. It matches the theory postulated by Ena (2013, p. 17) saying that students will be more engaged in the teaching and learning process when their culture were accommodated in the materials. The book has also covered the typical activities in the 
stages in Scientific Approach and the students' affective, cognitive and psychomotor domains of learning. It matches the theory of Scientific Approach proposed by Ministry of Education and Culture.

In terms of the content aspect, Textbook 1 is lacking in its retention as the writers do not provide sufficient materials and explanations related to the generic structure and the linguistic feature of the texts presented. It is not really in line with a theory from Richards (2001, p. 251252) stating that textbook can function as references to learn grammar. Added to that, in the production stage, the tasks for speaking and writing skills are not balance. Most of the production stage in the chapters are for students to produce language in the form written language. This textbook also has not really helped students to build interpersonal communication with others since it does not provide various example of conversation involving different people and situation. It does not meet one of the functions of textbook proposed by Richards (2001, p. 251252) claiming that textbooks can function as sources of activities for the students to practice their communicative interactions in order to communicate well in real life. Then, the contexts presented are limited to only on those related to school life. The list of expressions for transactional and interpersonal conversations are not provided in the textbook. The book is also lacking in terms of the materials and tasks which introduce students to the culture of English speaking country's people and promote international culture to raise students' awareness of diversity of English speakers.

For the language aspect, Textbook 1 is lacking in its unity and coherence of ideas among units meaning that this textbook does not have similarities between topics presented in each unit. In terms of the materials and activities for speaking, reading, grammar and pronunciation, they are still lacking since the number of the activities for those four aspects are limited.

In presentation aspect, Textbook 1 is still lacking in providing materials which facilitate students to be autonomous learners since the generic structure and linguistic features of some texts are not provided. The activities which facilitate one of the stages in scientific approach, namely Questioning are limited in the textbook. Added to that, the summary is only embedded in the reflection section. This textbook is also lacking in its glossary and index. Those two subaspects are not provided in the book.
Related to the affective, cognitive and psychomotor domains, Textbook 1 lacks the activities which reflect analyzing and evaluating stages in the cognitive domain. In terms of the psychomotor domain, this textbook is also lacking activities for set and adaptation stages in the psychomotor domain.

\section{Textbook 2}

Textbook 2 has been successful in providing the knowledge of generic structure and linguistic features in the texts presented. The tasks for all the four skills are balance. It provides various example of conversation involving different people and situation. The list of expressions for transactional and interpersonal conversations are provided in the textbook. They are relevant to the criteria from Cunningsworth (1995, p. 15-17) stating that the textbooks should facilitate the learning process in various ways and have a clear role as a support of learning. The book provides the materials and tasks which introduce students to the culture of English speaking country's people. It meets the theory proposed by Harmer $(2001$, p. 8) claiming that beside the local culture, the target culture which belongs to some countries in the inner circle should also be presented. It provides materials which facilitate students to be autonomous learners since the generic structure and linguistic features of some texts are provided. It has also covered the typical activities in the stages of the students' affective, cognitive and psychomotor domains of learning.

Textbook 2 has some weaknesses in the content aspect. The first one is that it lacks materials and tasks which contain texts and communicative events leading students to be aware of their local region's potential aspects in order to promote local and national potentials. This textbook is also lacking in terms of the materials which cover the local culture to maintain the students' identity. This point does not meet the theory stated by Ena (2013, p. 17) who believes that students are more engaged in the teaching and learning process when their culture were accommodated in the materials. The materials which promote international culture to raise the students' awareness of diversity of English speakers are also lacking.

In terms of the language aspect, Textbook 2 is lacking in two sub-aspects. The first one is that the textbook does not have coherence and unity of ideas among units. It does not have similarities between topics presented in each unit. 
The second sub-aspect is the presentation of materials and practices for teaching vocabulary aspect.

In presentation aspect, Textbook 2 is still lacking in providing the summary as it is only embedded in the reflection section. This textbook is also lacking in its glossary and index. Those two sub-aspects are not provided in the book.

Related to the coverage of affective, cognitive and psychomotor domains, Textbook 2 is still lacking in providing sufficient activities for Evaluating stage in cognitive domains and for Adaptation stage for psychomotor stage. They are mostly covered, but it is not sufficient.

\section{CONCLUSIONS}

The conclusions in this research are drawn from the findings and discussions presented previously aiming at answering the research questions of this study. The results show that When English Rings a Bell has fulfilled the criteria of a fair textbook (78.6\%). The book has several strengths. It provides: many texts as models; materials promoting the local culture; materials covering the stages in scientific approach, and materials covering three domains of learning. It also has some weaknesses. It lacks: retentions; tasks for production stage and conversations involving different situations; list of expressions for transactional and interpersonal conversations; materials promoting the target culture; the unity of ideas among units; materials for speaking, reading, grammar and pronunciation; materials for autonomous learning; also activities in Questioning stage, glossary and index, and activities in analyzing, evaluating, set and adaptation stages.

Meanwhile, Bright has fulfilled the criteria of a good textbook (87.2\%). It has some strengths. It provides: retentions; tasks for four skills, the list of expressions of transactional and interpersonal conversations, conversations involving different people and situations, materials containing western people culture, and activities in the stages of three domains of learning. This book has also weaknesses. It lacks: materials and tasks containing local and national potentials, the unity of ideas among units, glossary and index, and activities for Evaluating and Adaptation stages in the three domains of learning.

Through this research, it is also hoped that teachers will be able to evaluate and examine the textbooks they will use to teach students. The checklists which are designed to analyze the books can later be used to analyze other textbooks. Therefore, they will be able to take actions to improve and strengthen the materials after knowing the strengths and weaknesses.

The fact that actually there are many criteria of a good textbook should make the writers and publishers pay more attention to this aspect. It is because not all teachers are able to evaluate textbooks they use in the teaching and learning process since this process is quite demanding to conduct. Besides, it should be noted that not all teachers understand about how to adapt and modify some aspects which are still lacking in the textbooks. Based on the results of the findings, presentation aspect is the aspect which needs more attention since the summary of every unit, glossary containing difficult vocabularies and index of important words are missing in both textbooks being evaluated. One of the ways to overcome these problems will be building collaboration with English teachers and their associations such as MGMP, TEFLIN, and the like. This is beneficial because teachers are the parties who understand the students' needs most in the teaching learning process.

The researcher would like to give some recommendations to Pusat Perbukuan BSNP as the one which regulates the policy of textbook use in Indonesia. The findings of this study have showed that two textbooks are still lacking in some aspects. This requires Pusat Perbukuan $B S N P$ to give clear understanding about criteria of a good textbook to textbook writers and publishers. It will improve the quality of textbooks published since they will have the same perspective as Pusat Perbukuan BSNP.

One of the weaknesses of this study is that only two English textbooks which were evaluated and analyzed. Other researchers who are interested in the same field are recommended to evaluate and analyze other English textbooks which are used by teachers to teach all grades in Junior High School and Senior High School as this study only evaluated and analyzed textbooks for second graders of Junior High School. Textbook evaluation criteria from other experts can also be used to do that.

\section{REFERENCES}

Ary, D., Jacobs, L. C., Sorensen, C., \& Razavieh, A. (2010). Introduction to research in education. Belmont, California: Wadswoth Cengage Learning. 


\section{LingTera, 5 (1), 2018 - 40}

\section{Anita Nur Masyi'ah, Dyah Setyowati Ciptaningrum}

Boone, H.N. \& Boone, D. A. (2012). Analyzing likert data. Journal of extension, Volume 50 Number 2 Article Number 2TOT2.

Brown, H. D. (2001). Teaching by principles: an interactive approach to language pedagogy (second edition). Boston: Allyn and Bacon.

BSNP. (2011). Instrument penilaian I buku teks pelajaran bahasa Inggris SMP/MTs. Jakarta: Badan Standar Nasional Pendidikan.

BSNP. (2011). Instrument penilaian II buku teks pelajaran bahasa Inggris SMP/MTs. Jakarta: Badan Standar Nasional Pendidikan.

Byrd, P. (2001). Textbooks: Evaluation for selection and analysis for implementation. In Celce-Murcia, M. Teaching English as a second or foreign language ( $\left.3^{\text {rd }} \mathrm{ed}\right)$. US: Heinle \&Heinle.

Cunningsworth, A. (1984). Evaluating and selecting EFL teaching materials. Great Britain: Biddles Ltd.

Cunningsworth, A. (1995). Choosing your coursebook. Oxford: Heinemann.

Ena, O.T. (2013). Visual analysis of e-textbooks for senior high school in Indonesia. Unpublished EdD dissertation. Chicago: Loyola University.

Fatima, G., Shah, S. K., \& Sultan, H. (2015). Textbook analysis and evaluation of 7 th $\&$ 8th Grade in Pakistani context. International Journal of English Language Teaching, Vol.3, No.4, pp.79-97.

Harmer, J. (2001). The practice of English language teaching. Essex: Longman.

Hashemi, S. Z. \& Borhani, A. (2015). Textbook evaluation: An investigation into "American English File" Series. International Journal on Studies in English Language and Literature (IJSELL), Volume 3, Issue 5, 47-55.

Lathif, M. (2015). An evaluation of English textbooks for the eight graders of junior high school. Yogyakarta: State University of Yogyakarta.

Littlejohn, A. (2011). The analysis of language teaching materials: inside the Trojan
Horse. In Tomlinson, B. (Ed.) Materials Development in Language Teaching. Cambridge: Cambridge University Press. Pages 179-211

Ministry of Education and Culture. (2013). Implementasi Kurikulum 2013. Jakarta: Ministry of Education and Culture.

Ministry of Education and Culture. (2013). Konsep dan implementasi Kurikulum 2013. Jakarta: Ministry of Education and Culture.

Ministry of Education and Culture. (2014). When English Rings a Bell. Jakarta: Kemdikbud.

Mukundan, J., Nimehchisalem, V, \& Hajimohammadi, R. (2011). Developing an English language textbook evaluation checklist: A focus group discussion. International Journal of Humanities and Social Science, 1 (12), 100-106.

Nasution, S. (2008). Asas-asas kurikulum. Jakarta: Bumi Aksara.

Nuh, M. (2013). Bukan dihapus, mata pelajaran bahasa Inggris tidak wajib di SD. Accessed on $5^{\text {th }}$ of September 2014, from http://www.setkab. go.id/berita-11602mendikbud-bukan-dihapus-matapelajaran-bahasa-inggris-tidak-wajib-disd.html

Richards, J. C. (2001). Curriculum development in language teaching. Cambridge: Cambridge University Press.

Sitepu, B.P. (2012). Penulisan buku teks pelajaran. Bandung: PT Remaja Rosdakarya.

Tomlinson, B. (1998). Materials development in language teaching. Cambridge: Cambridge University Press.

Wahab, M. M. A. (2013). Developing an English language textbook evaluative checklist. IOSR Journal of Research \& Method in Education (IOSR-JRME). Vol 1, Issue 3. Available at http://www.iosrjournals.org.

Ur, P. (1996). A course in language teaching: practice and theory. Cambridge: Cambridge University Press.

Zaida, N. (2014). Bright. Jakarta: Erlangga. 